\title{
Subtractive Hybridization and Construction of cDNA Libraries
}

\section{Bruce Blumberg and Juan Carlos Izpisúa Belmonte}

\section{Introduction}

Genes that are differentially expressed both in time and space are the basis for how single cells, through the process of embryonic development, give rise to animals with an extraordinary diversity of cell types. As a first step in understanding differential gene expression, many researchers seek to identify those genes whose transcripts are temporally or spatially restricted to particular cells, tissues, or embryonic stages. Although there are a variety of methods suitable for identifying moderately to highly expressed genes, the isolation of the most interesting class of mRNAs, those that are not abundant, but that may be cellor tissue-specific, remains the most difficult task.

Several basic types of methods have been employed to identify low-abundance, tissue-specific transcripts. The more classical differential hybridization techniques (e.g., 1) are mostly limited to the detection of moderately abundant transcripts representing $>0.05 \%$ of the mRNA population (2). Subtractive hybridization techniques can increase the detection sensitivity by 10 - to 100 fold and make the identification of quite rare genes possible (2). A specialized form of subtractive hybridization, the "Gene Expression Screen" (3), can detect both upregulated and downregulated transcripts. A number of protocols have been devised in recent years to simplify and expedite the process of transcript identification by subtractive hybridization (4-8). Here we present a comprehensive set of methods that have proven quite successful in our laboratories and that may serve as an entry point for future refinement.

In the following protocol, we utilize the commonly available and widely used phage vector $\lambda$ ZAPII, since one can produce oriented libraries in phage or 
phagemids, and subsequently utilize the libraries to produce essentially unlimited quantities of sense or antisense RNAs for subtraction and screening. Furthermore, Stratagene (San Diego, CA) and other suppliers provide a number of high-quality, premade cDNA libraries that can save considerable time if one happens to exist for the tissue of interest. Recent advances in vector technology and hybridization allow one to produce subtracted probes and libraries even when starting material is quite limited.

\section{Materials}

\section{1. cDNA Synthesis}

1. 10X First-strand buffer: $0.5 \mathrm{M}$ Tris- $\mathrm{HCl}, \mathrm{pH} 8.9$ (this will be 8.3 at $42^{\circ} \mathrm{C}$ ), $0.1 \mathrm{M}$ $\mathrm{MgCl}_{2}, 0.2 \mathrm{M} \mathrm{KCl}, 50 \mathrm{mM}$ dithiothreitol (DTT).

2. 10X Second-strand buffer: $0.2 M$ Tris- $\mathrm{HCl}, \mathrm{pH} 7.5,0.05 \mathrm{M} \mathrm{MgCl}_{2}, 0.1 \mathrm{M}$ $\left(\mathrm{NH}_{4}\right)_{2} \mathrm{SO}_{4}, 1.0 \mathrm{M} \mathrm{KCl}$.

3. 10X EcoRI methylase buffer: $1.0 \mathrm{M}$ Tris- $\mathrm{HCl}, \mathrm{pH} 8.0,1.0 \mathrm{M} \mathrm{NaCl}, 0.01 M$ EDTA. Make as a stock solution and then add S-adenosyl methionine to $0.8 \mathrm{mM}$ to a small aliquot of this stock before use.

4. 10X T4 polynucleotide kinase buffer: $0.5 M$ Tris-HCl, pH 8.0, $0.1 M \mathrm{MgCl}_{2}, 50$ $\mathrm{m} M$ DTT.

5. 10X T4 ligase buffer: $0.3 M$ Tris- $\mathrm{HCl}, \mathrm{pH} 7.4,0.04 M \mathrm{MgCl}_{2}, 0.1 M$ DTT, $2 \mathrm{~m} M$ ATP. Make $\sim 10 \mathrm{~mL}$ of this buffer and store in $100-\mu \mathrm{L}$ aliquots at $-20^{\circ} \mathrm{C}$. Repeated freeze-thaw cycles rapidly deplete the buffer of both DTT and ATP.

6. dNTP mix with 5-methyl-dCTP: $20 \mathrm{~m} M$ dATP, $20 \mathrm{~m} M$ 5-methyl-dCTP, $20 \mathrm{~m} M$ dGTP, $20 \mathrm{~m} M$ dTTP.

7. dNTP mix: $20 \mathrm{~m} M$ dATP, $20 \mathrm{~m} M$ dCTP, $20 \mathrm{~m} M$ dGTP, $20 \mathrm{~m} M$ dTTP.

8. 10X EcoRI buffer-supplied by the manufacturer: $0.5 \mathrm{M}$ Tris-HCl, $\mathrm{pH}$ 7.5, 0.1 M $\mathrm{MgCl}_{2}, 1.0 \mathrm{M} \mathrm{NaCl}, 10 \mathrm{~m} M$ DTT.

9. Column buffer: $10 \mathrm{~m} M$ Tris-HCl, $\mathrm{pH} 8.0,1 \mathrm{~m} M$ EDTA, $0.15 \mathrm{M} \mathrm{NaCl}$.

10. TBE for electrophoresis (10X): $0.89 M$ Tris base (Boehringer Mannheim [BMB], Indianapolis, IN), $0.89 M$ boric acid, $0.02 M$ EDTA. Filter and autoclave (prevents precipitate from forming with time).

\subsection{Enzymes for cDNA Library Construction}

1. AMV reverse transcriptase (Seikagaku America \#120248-1 [St. Petersburg, FL]).

2. DNA polymerase I, endonuclease-free (BMB \# 642-711).

3. RNase H (Pharmacia \#27-0894-02 [Milwaukee, WI]).

4. T4 DNA polymerase (Pharmacia \#27-0718-02).

5. T4 polynucleotide kinase (Pharmacia \#27-0734-01).

6. T4 DNA ligase (Pharmacia \#27-0870-01).

7. T4 RNA ligase (Pharmacia \#27-0883-01).

8. Escherichia coli DNA ligase (BMB \#862 509).

9. EcoRI methylase (New England Biolabs, NEB \#211S [Tozier, MA], S-adenosyl methionine is supplied with the enzyme. 
10. Human placental ribonuclease inhibitor (Pharmacia RNA guard \#27-0815-01).

11. EcoRI high concentration (BMB \#200-310).

12. XhoI-high concentration (BMB \#703-788).

\subsection{Vectors and Packaging Extracts}

1. UniZAP-XR-ZAPII, digested with XhoI and EcoRI and dephosphorylated (Stratagene \#237211).

2. E. coli (ER-1647 NEB \#401-N).

3. Gigapack II Gold packaging extract (Stratagene \#200216).

\subsection{Miscellaneous Reagents and Supplies for cDNA Synthesis}

1. A primer consisting of $\sim 15$ Ts followed by at least an XhoI site and preferably several other rare sites. The one we use is 5'(ACTAGTGCGGCCGCCTAG GCCTCGAGTTTTTTTTTTTTTTT)3'.

This has the following restriction sites (in 5' -> 3' order): SpeI, NotI, EagI, SfiI, AvrII, StuI, XhoI.

2. EcoRI linkers-octamer (GGAATTCC) (Pharmacia 5'-OH, \#27-7726-01, 5'-PO \#27-7428-01).

3. 5-methyl-dCTP (Pharmacia \#27-4225-01). Store as a 100-mM stock.

4. dNTPs (Pharmacia \#27-2035-01). $100 \mathrm{mM}$ solutions of each.

5. $10 \mathrm{mM}$ ATP (Pharmacia \#27-2056-01) (dilute from $100 \mathrm{mM}$ stock).

6. $0.1 M \mathrm{CH}_{3} \mathrm{HgOH}$ (ALFA products \#89691).

7. 5.8 M 2-mercaptoethanol (BME; Sigma M6250 [St. Louis, MO]).

8. $100 \%$ Ethanol (Rossvile Gold Shield or equivalent).

9. $\alpha\left[{ }^{32} \mathrm{P}\right]$-dATP $800 \mathrm{Ci} / \mathrm{m} M$ (New England Nuclear, Wilmington, DE, \#NEG-012A).

10. $\gamma\left[{ }^{32} \mathrm{P}\right] \mathrm{ATP} 6000 \mathrm{Ci} / \mathrm{m} M$ (New England Nuclear \#NEG-002Z).

11. 1-kb Ladder (BRL \#5615SA).

12. Agarose (Pharmacia \#17-0554-02 or Bio-Rad, Hercules, CA, \#162-0126).

13. $40 \%$ acrylamide (19:1 acrylamide:bisacrylamide) acrylamide (Bio-Rad \#1610101), bis-acrylamide (Bio-Rad \#161-0201).

14. $\beta$-NAD (BMB \#775-7). The stock solution is $0.045 M$ in $\mathrm{H}_{2} \mathrm{O}$.

15. Sepharose Cl-4B (Pharmacia \#17-0150-01) equilibrated in column buffer.

16. Tris-base (BMB \#604-205).

17. X-gal (BMB \#745-710).

18. IPTG (BMB \#724-815).

19. Ultrapure, recrystallized phenol (BMB \#100-300).

20. DTT (BMB \#100-032).

21. Sodium dodecyl sulfate (SDS) (BMB \#100-155).

22. Guanidine $\mathrm{HCl}$ (optional) (BMB \#100-173 or BRL \#5502UA).

23. Guanidine thiocyanate (BMB \#100-175 or BRL \#5535UA).

24. Ultrapure urea (BMB \#100-164).

25. LiCl (Sigma L-0505).

26. Sephadex G-50 spun columns, equilibrated in TE Sephadex G-50 medium (Pharmacia \#17-0043-01), or Sephadex G-50 spun columns (Pharmacia \#17-0855-01). 
27. LB media and plates.

28. Minimal media and plates (use maltose as carbon source).

29. 20\% Maltose (Difco).

30. All other chemicals and reagents should be at least ACS-reagent grade. You cannot go wrong by buying small quantities of ultrapure chemicals (e.g., from Aldrich) and reserving them for making cDNA buffers and solutions.

\subsection{Reagents for Biotinylation and Subtraction}

1. Photobiotin acetate (Clontech K1012-1 [Palo Alto, CA]).

2. Reflector sunlamp (Clontech 1131-3).

3. Biotin-21-UTP (Clontech 5024-1).

4. Streptavidin (BRL Life Technologies \#15532-013 [Gaithersburg, MD]).

\subsection{Reagents for Isolation of Total RNA}

1. Guanidine thiocyanate solution (GuSCN): $4.0 \mathrm{M}$ guanidine thiocyanate (BMB \#100-175), $0.01 M$ Na-acetate, $\mathrm{pH}$ 7.0, $0.1 \mathrm{M}$ 2-mercaptoethanol (Sigma), 0.1\% (w/v) $n$-lauryl sarcosine (Sigma), $0.5 \%$ (v/v) antifoam C (Sigma).

2. CsCl-EDTA cushion: $6.0 \mathrm{M} \mathrm{CsCl}$ (BMB), 0.1 M EDTA, pH 7.0.

3. Phenol:chloroform:isoamyl alcohol: 25 parts ultrapure phenol (BMB \#100-300), 24 parts chloroform (Fisher ACS grade, Fisher Scientific, Pittsburgh, PA), 1 part isoamyl alcohol (Fisher ACS grade). Prepared as described in ref. 9.

4. Chloroform:isoamyl alcohol: 24 parts chloroform, 1 part isoamyl alcohol, store at room temperature in a dark bottle.

5. Ethanol-sodium acetate: $0.04 \mathrm{M} \mathrm{Na}$-acetate, $60 \% \mathrm{v} / \mathrm{v}$ ethanol, prepare by mixing 3 parts of $80 \%$ ethanol with 1 part of $0.15 M$ Na-acetate, $\mathrm{pH} 7.0$.

6. Ammonium acetate for precipitations: 7.5 $M$ NH4-acetate $\mathrm{pH} 7.0$-treat with $0.2 \%$ DEPC and autoclave. Store at $-20^{\circ} \mathrm{C}$.

\subsection{Reagents for Poly A+ Selection}

1. 2X Loading buffer: $40 \mathrm{~m} M$ Tris-HCl, $\mathrm{pH}$ 7.6, $1 M \mathrm{NaCl}, 2 \mathrm{~m} M$ EDTA, 0.2\% SDS.

2. $0.1 \mathrm{~N} \mathrm{NaOH}$.

3. Loading buffer (low-salt): $40 \mathrm{~m} M$ Tris-HCl, $\mathrm{pH}$ 7.6, $0.1 M \mathrm{NaCl}, 2 \mathrm{~m} M$ EDTA, $0.2 \%$ SDS.

4. Elution buffer: $10 \mathrm{~m} M$ Tris-HCI, pH 7.5, $1 \mathrm{~m} M$ EDTA, 0.05\% SDS.

5. $3 M$ sodium acetate, $\mathrm{pH} 5.2$.

6. $100 \%$ Ethanol (reserved for RNA use).

7. $70 \%$ Ethanol (reserved for RNA use).

8. Oligo (dT) cellulose, Type 2 (Collaborative Research, Los Altos, CA, cat. \# 20002).

9. Quik-Sep columns (Isolab, Akron, OH, cat. \# QS-Q).

\subsection{Reagents for In Vitro Transcription (Optional)}

1. Megascript T7 kit (Ambion, Austin, TX, \#1334).

2. Megascript T3 kit (Ambion \#1338). 


\section{Methods}

Whether to produce subtracted cDNA libraries or screen standard libraries with subtracted probes is the first consideration one must address. We advocate the construction of representative cDNA libraries that can later be screened with any desired probe. Indeed, such libraries can also be used to produce either synthetic driver or target mRNAs in large quantitites. This approach has the advantage that only one or two libraries must be constructed for each target/driver pair, and any type of probe can be used as may later be required. It has the disadvantage that more clones must be screened to ensure the representation of the rarest mRNAs.

The choice of subtraction protocol to be followed depends on the availability of mRNA from both target and driver cells or tissues. If the driver mRNA is not limiting ( $\sim 50 \mu \mathrm{g}$ available) then one can begin with Subheading 3.7., photobiotinylation of driver mRNA, otherwise one should first construct a library which may then be used to generate driver RNA. Similarly, the abundance of target mRNA and the desire to produce a representative or subtracted library will dictate whether the target will be oligodT-primed first strand cDNA or random primed cDNA produced after in vitro transcription of the library (Fig. 1).

\subsection{Preparation of Total RNA (Based on Ref. 10)}

1. There are a number of quite good procedures for preparing high-quality RNA. In addition, several commercial kits are available for this purpose that work reasonably well, but are rather expensive. The method appropriate for your cells or tissue depends largely on the amount of endogenous RNases present. The following method is somewhat tedious but always gives high-quality RNA.

2. Homogenization - the tissue is homogenized in 5 vol of ice-cold GuSCN solution on ice with two 30-s bursts of the polytron at maximum speed. Be sure that the tissue is completely dispersed. The size of polytron generator used depends on the quantity of tissue, but for most cases, the 1-cm type is adequate. For hard tissues, such as bone, a generator with blades should be used. Cultured cells are first trypsinized, rinsed with PBS, and resuspended in a minimum volume of PBS. Each $1 \mathrm{~mL}$ of densely suspended cells is homogenized in $\sim 10 \mathrm{~mL}$ of icecold GuSCN solution on ice as above. It is convenient to use sterile, disposable 50-mL polypropylene tubes for both homogenization and extractions.

3. Extract the homogenate with phenol:chloroform once and centrifuge to separate the layers for $5 \mathrm{~min}$ at $3000 \mathrm{~g}$. The upper, aqueous layer will appear somewhat milky, and is removed to a fresh tube. If you just use phenol instead of phenol chloroform, there will be no phase separation.

4. Extract the aqueous layer once with an equal volume of chloroform:isoamyl alcohol and centrifuge as above.

5. Centrifugation - the homogenate is layered onto 2.2-mL cushions of CsCl-EDTA solution prepared in SW-41 tubes. Centrifugation is for $18 \mathrm{~h}$ at 28,000 rpm at $20^{\circ} \mathrm{C}$ in an SW-41 rotor. 


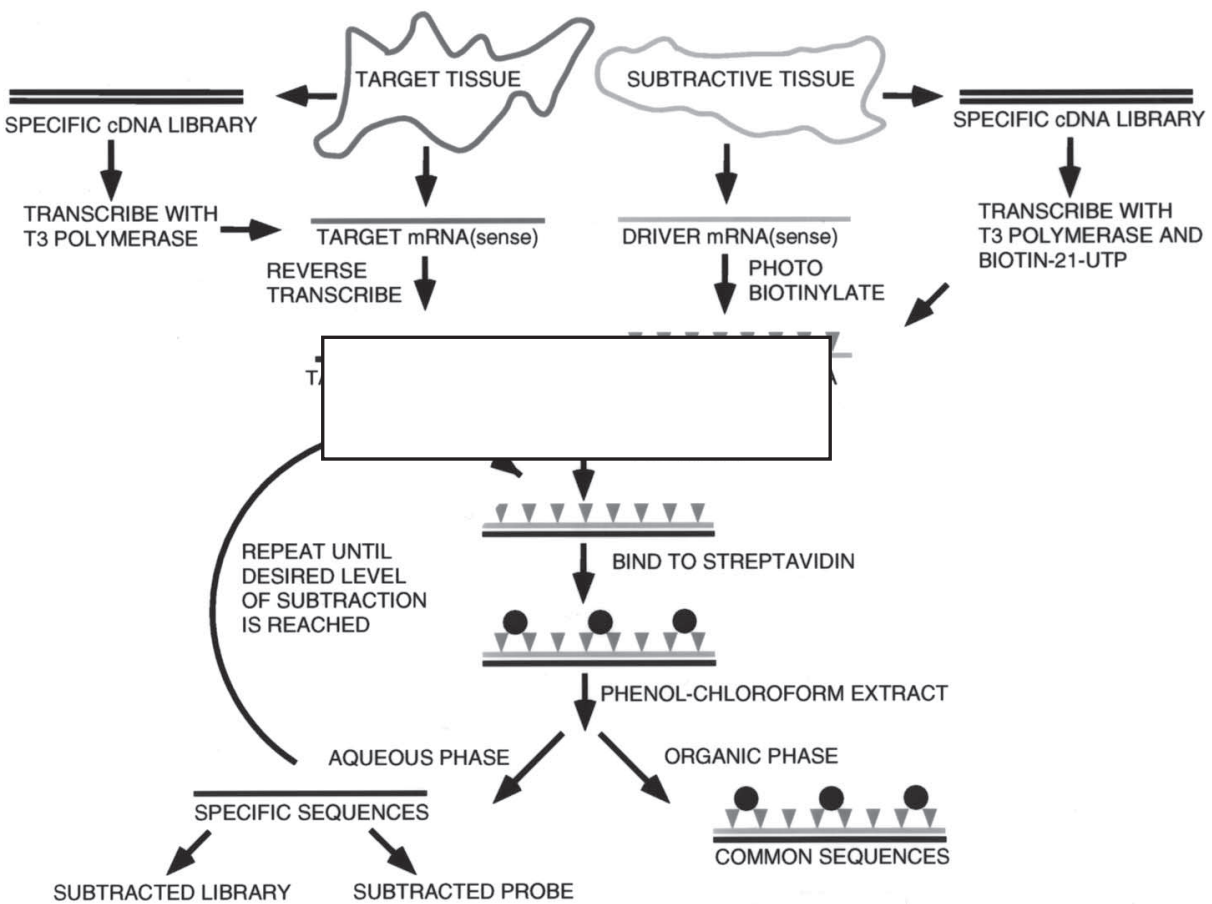

Fig. 1. Schematic view of the steps in constructing a subtracted cDNA library or subtracted probe. (See color plate 1 appearing after p. 368.)

If an SW-28 or SW-27 rotor is used, then the centrifugation speed should be decreased to $22,000 \mathrm{rpm}$. If other rotors are used, the volume of the cushion should be one-fifth of the total tube volume. Be sure to check the rotor manual to determine the maximum rotor speed with concentrated $\mathrm{CsCl}$ solutions.

6. Collection of the RNA - the tubes are removed from the centrifuge and placed in a rack.

7. The GuSCN layer is aspirated down to and including $\sim 0.5 \mathrm{~mL}$ of the cushion. The tube is carefully filled with DEPC containing $\mathrm{H}_{2} \mathrm{O}$, allowed to stand 2-5 min, and then the water is aspirated. This is repeated twice.

8. After the final rinse, the tube is quickly inverted and allowed to drain. The bottom $2 \mathrm{~cm}$ of the tube are cut off with a fresh scalpel, and the tube placed upright in a rack. The RNA appears as a glistening button in the center of the tube. Small amounts of RNA may not be visible. The pellet is carefully rinsed with $0.5 \mathrm{~mL}$ of DEPC-treated $\mathrm{H}_{2} \mathrm{O}$, and the tube inverted to dry.

9. The pellet is then macerated with, and taken up into a tip containing $\sim 100 \mu \mathrm{L}$ of DEPC-treated $\mathrm{H}_{2} \mathrm{O}$ (or an appropriate amount for the RNA yield you end up with). The RNA is pipeted up and down and transferred to an Eppendorf tube. Be sure you transfer all the RNA. The RNA is then heated at $70^{\circ} \mathrm{C}$ for $2-30$ min until dissolved. Large amounts of RNA need longer times and require more $\mathrm{H}_{2} \mathrm{O}$. The 
insoluble debris is removed by brief centrifugation, and the supernatant removed to a fresh Eppendorf tube.

10. Add 0.5 vol of $\mathrm{NH}_{4}$-acetate and 2 vol (i.e., $2 \mathrm{X}$ the volume of the RNA + acetate solution) of absolute ethanol. Precipitate for $15 \mathrm{~min}$ at $-70^{\circ} \mathrm{C}$ or several hours to overnight at $-20^{\circ} \mathrm{C}$ (preferred method). Centrifuge for $15-30 \mathrm{~min}$ at $4^{\circ} \mathrm{C}$, and then drain the supernatant. Rinse the pellet three times with the ethanol-sodium acetate solution, centrifuging briefly between rinses.

11. Rinse the pellet once with $80 \%$ ethanol, once with $100 \%$ ethanol, and air-dry. Resuspend the RNA in an appropriate volume of $\mathrm{H}_{2} \mathrm{O}$, and store at $-70^{\circ} \mathrm{C}$.

\subsection{Evaluation of RNA Quality}

1. Quantitate the RNA by spectrophotometry. $\mathrm{OD}_{260: 280}$ ratios should be 1.8 or greater, although tissues containing significant quantities of proteoglycans may give lower ratios. If the ratio is too low, phenol-extract, chloroform-extract, and ethanol-precipitate the RNA one or more times.

2. Evaluate the integrity of the RNA by gel electrophoresis, either denaturing or nondenaturing.

3. Nondenaturing agarose gels: The simplest method is to run a $0.8 \%$ agarose gel containing $100 \mu \mathrm{g} / \mathrm{mL}$ ethidium bromide (EtBr), using TBE as the running buffer, just as for a normal DNA gel.

4. Denaturing gel-use a $0.8 \%$ formaldehyde-agarose gel run in MOPS-acetate buffer as described in ref. (9). Stain with ethidium bromide for 30', and view under UV.

5. The $28 \mathrm{~S}$ and $18 \mathrm{~S}$ rRNA bands should be sharp and in a 2:1 ratio. Some organisms, e.g., Drosophila melanogaster and Alligator mississipiensis, have $28 \mathrm{~S}$ rRNAs, which are nicked and migrate with the $18 \mathrm{~S}$ bands in denaturing gels. Use nondenaturing gels with these organisms and if you do not see the $28 \mathrm{~S}$ band in denaturing gels.

6. Storage of RNA-store at $-70^{\circ} \mathrm{C}$ in $\mathrm{H}_{2} \mathrm{O}$ or as an ethanol precipitate at $-20^{\circ} \mathrm{C}$ (preferred).

\subsection{Preparation of Poly $A^{+}$RNA}

1. Once the isolation of total RNA is complete, isolation of mRNA can be performed by affinity chromatography on oligo (dT) cellulose, since the vast majority of mRNAs of mammalian cells carry tracts of poly (A) at their 3'termini. Several companies make kits for preparing poly $A^{+}$RNA. We have had success with those by Qiagen (75022 or 70042 [Los Angeles, CA]) and Invitrogen (K1520-02 [San Diego, CA]). We also describe here a reliable protocol that we have been routinely using before changing to the commercially available kit.

2. Equilibrate the oligo (dT) cellulose in sterile loading buffer. Binding affinity is batch-specific. However, a good rule of thumb is that $1 \mathrm{~g}$ of resin will bind 2-2.5 mg of poly $(\mathrm{A})+\mathrm{RNA}$.

3. Pour $1.0 \mathrm{~mL}$ packed volume of oligo (dT) cellulose in the Quik-Sep column. 
4. Wash the column with, successively, three column volumes of sterile DEPCtreated $\mathrm{H}_{2} \mathrm{O}, 0.1 \mathrm{~N} \mathrm{NaOH}$, sterile DEPC-treated $\mathrm{H}_{2} \mathrm{O}$. Continue the last wash step until the $\mathrm{pH}$ of the column effluent is $<8.0$.

5. Wash the column with $5 \mathrm{vol}$ of sterile loading buffer.

6. Dissolve the total RNA in sterile water. Heat to $65^{\circ} \mathrm{C}$ for $5 \mathrm{~min}$. Add an equal amount of $2 \mathrm{X}$ loading buffer, and cool the sample to room temperature.

7. Apply the sample to the column, and allow to flow through by gravity. Collect the flow-through.

8. Heat the flow-through to $65^{\circ} \mathrm{C}$, cool, and reapply to the column as above.

9. Wash the column with 5-10 column volumes of loading buffer, followed by four column volumes of low-salt loading buffer. The first RNA to elute off the column will be the poly (A)- fraction. The poly (A)+ fraction will elute with the nosalt elution buffer.

10. Elute the poly (A)+ RNA with two to three column volumes of sterile elution buffer. The eluted poly (A)+ RNA can be selected again on oligo (dT)-cellulose by adjusting the $\mathrm{NaCl}$ concentration of the eluted RNA to $0.5 \mathrm{M}$ and repeating steps 6-10. We generally elute into Falcon 2059 polypropylene tubes $(17 \times 100-\mathrm{mm})$.

11. Add sodium acetate ( $3 M, \mathrm{pH}$ 5.2) to a final concentration of $0.3 M$. Precipitate the RNA with $2.5 \mathrm{vol}$ of $100 \%$ ethanol at $-20^{\circ} \mathrm{C}$ overnight.

12. Spin the precipitated RNA at $10,000 \mathrm{rpm}(12,000 \mathrm{~g})$ for $30 \mathrm{~min}$. Carefully aspirate the supernatant, rinse the pellet with $70 \% \mathrm{EtOH}$, and air-dry. Resuspend the RNA pellet in an appropriate volume of DEPC-treated $\mathrm{H}_{2} \mathrm{O}$. Determine the RNA concentration spectrophotometrically. Reprecipitate and store as an ethanol precipitate at $-20^{\circ} \mathrm{C}$. RNA is most stable when stored under ethanol at $-70^{\circ} \mathrm{C}$.

\subsection{Preparation of a Directional cDNA Library (Ref. 11)}

\subsubsection{First-Strand Synthesis}

1. Use $20-400 \mu \mathrm{g}$ of total cellular RNA ( $150 \mu \mathrm{g}$ seems sufficient) or $1-5 \mu \mathrm{g}$ of poly (A)+ RNA. Precipitate the RNA if necessary such that the final volume of the RNA will be $28 \mu \mathrm{L}$.

2. Denature the RNA by adding $5 \mu \mathrm{L}$ of $0.1 M$ methylmercuric hydroxide (see Note 1) and incubating for $5 \mathrm{~min}$ at room temperature. Quench the reaction with $0.5 \mu \mathrm{L}$ of 5.8 M 2-mercaptoethanol, and incubate for $5 \mathrm{~min}$ at room temperature.

3. The reaction mixture is then assembled as follows:

$33.5 \mu \mathrm{L}$ RNA mixture (from Subheading 3.4.1., step 2);

$6.0 \mu \mathrm{L} 10 \mathrm{X}$ first strand buffer;

$6.0 \mu \mathrm{L} 20 \mathrm{~m} M$ dNTPs containing 5-methyl-dCTP;

$3.0 \mu \mathrm{L} 80 \mathrm{~m} M$ Na-pyrophosphate;

$2.0 \mu \mathrm{L}$ primer $(5 \mathrm{mg} / \mathrm{mL})$;

$2.0 \mu \mathrm{L}{ }^{32} \mathrm{P}-\mathrm{dATP}$

$3.0 \mu \mathrm{L}$ placental RNAse inhibitor (30-100 U);

$5.0 \mu \mathrm{L}$ AMV reverse transcriptase (50-100 U);

Incubate at $42^{\circ} \mathrm{C}$ for $1 \mathrm{~h}$. Add $3 \mu \mathrm{L}$ reverse transcriptase and incubate for $1 \mathrm{~h}$ more. 
4. Determine the percent incorporation by TCA precipitation. Remove $2 \mu \mathrm{L}$ of the reaction mix. Add $8 \mu \mathrm{L}$ of DEPC-treated $\mathrm{H}_{2} \mathrm{O}$, and spot $5 \mu \mathrm{L}$ onto a Whatman GFC filter and reserve it. To the other $5 \mu \mathrm{L}$, add $25 \mu \mathrm{L}$ of $2 \mathrm{mg} / \mathrm{mL}$ bovine serum albumin (BSA) and $100 \mu \mathrm{L}$ of $20 \%$ trichloroacetic acid (TCA). Incubate on ice for $30 \mathrm{~min}$, and then filter through GFC in a vacuum filtration device. Wash with $20 \mathrm{~mL}$ of $5 \% \mathrm{TCA}$, and then dry the filter for $20 \mathrm{~min}$ at $60^{\circ} \mathrm{C}$ or under a heat lamp. Transfer both filters to scintillation vials, add scintillation fluid, and count. Determine the percent incorporation of the trace label into cDNA. The yield in nanograms of cDNA is incorporation $\times 120$ (nmol each nucleotide) $\times 4$ (nucleotides) $\times 330$ ( $\mathrm{g} / \mathrm{mol}$ of nucleotide).

5. Dilute the cDNA to $150 \mu \mathrm{L}$ and load onto a $1 \mathrm{~mL}$ Sephadex G-50 spun column in TE. Spin for $3 \mathrm{~min}$ at $1000 \mathrm{rpm}$, and collect the flowthrough. Measure the volume by weighing the liquid and assuming $1 \mathrm{~g} / \mathrm{mL}$ for $\mathrm{H}_{2} \mathrm{O}$. This step is necessary to remove 5-methyl-dCTP. Any remaining will be incorporated into the second strand and prevent cleavage at the 3' XhoI site.

\subsubsection{Second-Strand Synthesis}

1. The reaction mix is assembled as follows:

$\mathrm{xx} \mu \mathrm{L}$ first-strand reaction $(\sim 125-150 \mu \mathrm{L})$;

$30 \mu \mathrm{L} 10 \mathrm{X}$ second-strand buffer;

$30 \mu \mathrm{L} 20 \mathrm{~m} M$ dNTPs;

$3 \mu \mathrm{L}$ RNase $\mathrm{H}(\sim 2.5 \mathrm{U})$;

$1 \mu \mathrm{L} 45 \mathrm{~m} M \beta$-NAD;

$1 \mu \mathrm{L}$ E. coli DNA ligase ( 250 ng);

$12 \mu \mathrm{L}$ DNA polymerase I ( $\sim 80 \mathrm{U})$;

xxx $\mu \mathrm{L} \mathrm{H}_{2} \mathrm{O}$ - to a final volume of $300 \mu \mathrm{L}$;

2. Incubate overnight at $14^{\circ} \mathrm{C}$.

3. Heat at $80^{\circ} \mathrm{C}$ for $15 \mathrm{~min}$, cool on ice, and spin briefly to collect the liquid.

4. Add $\sim 20 \mathrm{U}$ of T4 DNA polymerase, and incubate $1 \mathrm{~h}$ at $37^{\circ} \mathrm{C}$ (see Note 2 ).

5. Phenol extract, ethanol precipitate, rinse, and dry.

\subsubsection{EcoRI Methylase Treatment}

1. Resuspend the cDNA in $85 \mu \mathrm{L}$ of $\mathrm{H}_{2} \mathrm{O}$. The reaction mixture is as follows:

$85 \mu \mathrm{L} \mathrm{cDNA}$;

$11 \mu \mathrm{L} 10 \mathrm{X}$ methylase buffer;

$10 \mu \mathrm{L}$ EcoRI methylase (100-400 U).

Incubate for $30 \mathrm{~min}$ at $37^{\circ} \mathrm{C}$. Add $4 \mu \mathrm{L}$ more methylase and incubate for $30 \mathrm{~min}$ longer.

2. Heat $80^{\circ} \mathrm{C}$ for $15 \mathrm{~min}$, then cool on ice

3. Add $1 \mu \mathrm{L}$ of $20 \mathrm{~m} M$ dNTP's and $1 \mathrm{U}$ of T4 DNA polymerase. Incubate for $30 \mathrm{~min}$ at $37^{\circ} \mathrm{C}$ (see Note 3 ).

4. Phenol-extract, ethanol-precipitate, rinse, and dry the cDNA.

\subsubsection{Kinase Linkers}

1. $0.8 \mu \mathrm{g}$ of ${ }^{32} \mathrm{P}$-labeled linkers is needed for each cDNA preparation (see Note 4). An example reaction is the following: 
$8 \mu \mathrm{L}$ linkers $=4 \mu \mathrm{g}$;

$2 \mu \mathrm{L} 10$ kinase buffer;

$1 \mu \mathrm{L} \alpha-{ }^{32} \mathrm{P}-\mathrm{ATP}$;

$1 \mu \mathrm{L}$ T4 polynucleotide kinase ( $\sim \mathrm{U})$;

$8 \mu \mathrm{L} \mathrm{H}_{2} \mathrm{O}$.

Incubate for $15 \mathrm{~min}$ at $37^{\circ} \mathrm{C}$.

2. Add:

$1 \mu \mathrm{L} 10 \mathrm{X}$ kinase buffer;

$4 \mu \mathrm{L} 10 \mathrm{~m} M$ ATP;

$1 \mu \mathrm{L} \mathrm{T} 4$ polynucleotide kinase;

$4 \mu \mathrm{L} \mathrm{ddH} \mathrm{H}_{2} \mathrm{O}$.

Incubate for $45 \mathrm{~min}$ at $37^{\circ} \mathrm{C}$.

3. Heat-kill the enzyme at $80^{\circ} \mathrm{C}$ for $15 \mathrm{~min}$, and then cool on ice.

\subsubsection{Linker Ligation (see Note 5)}

1. Resuspend cDNA in $27 \mu \mathrm{LddH_{2 }} \mathrm{O}$. An example reaction is the following:

$27 \mu \mathrm{L}$ cDNA;

$5 \mu \mathrm{L} 10 \mathrm{X}$ ligase buffer;

$5 \mu \mathrm{L} 10 \mathrm{~m} M$ ATP;

$6 \mu \mathrm{L}{ }^{32} \mathrm{P}$-labeled linkers- $-0.8 \mu \mathrm{g}$;

$3 \mu \mathrm{L}$ unlabeled linkers $-3 \mu \mathrm{g}$;

$2 \mu \mathrm{L}$ T4 DNA ligase-10-20 Weiss U;

$2 \mu \mathrm{L}$ T4 RNA ligase-12-18 U (see Note 6).

Incubate for $1 \mathrm{~h}$ at room temperature then $14^{\circ} \mathrm{C}$ overnight.

2. Heat-kill the enzyme at $80^{\circ} \mathrm{C}$ for $15 \mathrm{~min}$, and then cool on ice.

3. Remove $1 \mu \mathrm{L}$ of the ligation mix to test for ligation (see Note 7).

\subsubsection{EcoRI Digestion}

1. An example reaction is the following:

$49 \mu \mathrm{L}$ ligation mix.

$20 \mu \mathrm{L} 10 \mathrm{X}$ buffer $\mathrm{H}$.

$126 \mu \mathrm{L} \mathrm{ddH}_{2} \mathrm{O}$.

$5 \mu \mathrm{L} \operatorname{EcoRI}(\sim 450 \mathrm{U})$.

Incubate for $1 \mathrm{~h}$ at $37^{\circ} \mathrm{C}$.

2. Add $2 \mu \mathrm{L}$ more enzyme and incubate $1 \mathrm{~h}$ more.

3. Remove $4 \mu \mathrm{L}$ to check for digestion (see Note 7).

4. Optionally, save a portion for cloning into EcoRI cut vector.

\subsubsection{Xhol Digestion (see Note 8)}

1. Make the reaction mix $150 \mathrm{mM}$ in $\mathrm{NaCl}$ by adding $\mathrm{NaCl}$ and $\mathrm{H}_{2} \mathrm{O}$. XhoI cuts better in this increased salt concentration.

2. Add $5 \mu \mathrm{L}$ of $\mathrm{XhoI}(\sim 250-500 \mathrm{U})$, and incubate $2 \mathrm{~h}$ at $37^{\circ} \mathrm{C}$.

3. Save a $5-\mu \mathrm{L}$ aliquot to check the digestion.

4. Phenol-extract, ethanol-precipitate, rinse, and dry the cDNA. 


\subsubsection{Removal of Linkers and Small cDNAs}

1. Pour a column in a 1-mL disposable pipet plugged with sterile polyester wool (see Note 9).

2. Make a reservoir with a 2-mL disposable Pasteur pipet cutting the bottom off at the appropriate level and slipping over the end of the column. Now cut the very top of the pipet off, fill, and rinse with $10 \mathrm{~mL}$ of column buffer.

3. Resuspend the cDNA in $50 \mu \mathrm{L}$ of column buffer, and apply to the column (see Note 10).

4. Monitor the progress of the radioactivity into the column with a Geiger counter. When it gets one-third of the way $(\sim 250 \mu \mathrm{L})$, start collecting two-drop fractions into microfuge tubes. Continue collecting fractions until the major ${ }^{32} \mathrm{P}$ peak (linkers) reaches the bottom.

5. Count the all of the fractions by Cerenkov counting, and plot the results. You should see two distinct peaks.

6. Run aliquots of alternate column fractions on a $1 \%$ agarose gel with labeled $1-\mathrm{kb}$ ladder and unlabeled 1-kb ladder.

7. Dry the gel and expose to film. Pool the peaks containing cDNA from about $500 \mathrm{bp}$ to the beginning of the column (see Note 11).

\subsubsection{Ligation to Vector}

1. Add an appropriate amount of vector to the pooled cDNA and ethanol-precipitate (overnight is best), rinse carefully, and dry (see Note 12). Try to use about 10X the weight in cDNA of $\lambda$ arms. The use of less will result in a significant proportion of clones containing multiple inserts, although the total number of clones will increase.

2. Resuspend the cDNA/vector pellet in $5 \mu \mathrm{L}$ of ligation cocktail, which contains the following:

$0.5 \mu \mathrm{L} 10 \mathrm{X}$ ligation buffer;

$0.5 \mu \mathrm{L} 10 \mathrm{~m} M$ ATP;

$2.0 \mu \mathrm{L}$ T4 ligase (10-12 Weiss units);

$2.0 \mu \mathrm{L} \mathrm{ddH_{2 }} \mathrm{O}$.

3. Be sure the pellet is completely dissolved, and centrifuge to put everything into the bottom of the tube.

4. Ligate at $14^{\circ} \mathrm{C}$ overnight.

\subsubsection{Packaging and Titering the Library}

1. Package the ligation mix as directed in the instructions accompanying the packaging mix (Note13).

2. Dilute the packaged phage with $500 \mu \mathrm{L}$ of SM, and add $20 \mu \mathrm{L}$ of chloroform (not chloroform:isoamyl alcohol). Store in the dark at $4^{\circ} \mathrm{C}$.

3. Plate 1,10 , and $100 \mu \mathrm{L}$ of a $10^{-3}$ dilution on $300 \mu \mathrm{L}$ of ER-1647 plating cells grown as described below. Adsorb the phage to the plating cells for 15-30 min at room temperature, and then transfer to $37^{\circ} \mathrm{C}$ for $5 \mathrm{~min}$. Phage can adsorb to the 
receptors, but cannot inject their DNA at room temperature. The transfer to $37^{\circ} \mathrm{C}$ produces a relatively synchronous infection. Incubate at $37^{\circ} \mathrm{C}$ for $8 \mathrm{~h}$ to overnight. It is essential that the strain used be deficient in methylcytosine restriction $\left(\mathrm{mcrA}^{-}, \mathrm{mcrBC}^{-}\right)$.

4. Determining the fraction of recombinant clones in the library. Since ER1647 is lac-, the library must be plated on an appropriate strain that allows a complementation and is McrABC-, like YS-1, or amplified first on ER-1647 and then plated on XL1-Blue. After amplification, the fraction of recombinants can be determined by plating on XL1-Blue with X-gal and IPTG as described above. Using UniZap-XR, a typical yield is $95+\%$ recombinant phages.

\subsubsection{Preparation of E. coli for Plating Libraries (see Note 14)}

1. Maintain strains for growth on minimal plates, using maltose as the carbon source and supplemented with the appropriate auxotrophic requirements. ER-1647 requires histidine, methionine, and tryptophane.

2. Grow a single colony overnight in an appropriate volume of minimal medium with the required supplements.

3. Spin down the overnight cells and resuspend in $0.5 \mathrm{vol}$ of $10 \mathrm{mM} \mathrm{MgSO}$. The cells are stable for about a month when resuspended in $10 \mathrm{mM} \mathrm{MgSO}$, but only a few days if not. Of course, fresh cells work better.

4. Use $200-300 \mu \mathrm{L}$ of cells for a $100-\mathrm{mm}$ plate or $600-800$ for a $150-\mathrm{mm}$ plate. In vitro packaging mixes contain a large excess of phage tails, so use the larger volume for them. Maltose-grown cells also help a lot.

\subsubsection{Amplification of Libraries}

1. It is beneficial to screen unamplified libraries, since one needs to screen fewer clones; however, it is better to amplify the library for permanent storage. A good practice is to reserve a portion of the library unamplified and amplify the remainder for permanent storage.

2. It is convenient to plate $100-150 \times 10^{3}$ phage/fresh $150-\mathrm{mm}$ plate. We prefer to plate in the morning and observe phage growth during the day. When plaques are touching, overlay each plate with $15 \mathrm{~mL}$ of $\mathrm{SM}$, and incubate at $4^{\circ} \mathrm{C}$ overnight with shaking if possible. Plaques grown this way will typically be only 1-2 mm in diameter.

3. Harvest the liquid and make it $5.0 \%$ in chloroform. Be sure to use fresh chloroform that has been stored in the dark, because photodegradation products of chloroform are reportedly toxic to phage.

4. Spin out the debris, and transfer the lysate to an appropriate container. For storage at $4{ }^{\circ} \mathrm{C}$ make the lysate $5 \%$ chloroform and store in the dark. A foil-covered Erlenmeyer flask, or media bottle is a good choice. The chloroform inhibits the growth of molds, which cause the library titer to drop rapidly.

5. It is probably a good idea to store aliquots of the library at $-70^{\circ} \mathrm{C}$ for permanent storage. Bring the lysate to $7 \%$ DMSO, and freeze conveniently sized aliquots. 


\section{5. $\lambda$ Phage Minipreps}

1. In order to prepare synthetic RNA from a $\lambda$ ZAPII library, one must first prepare a sufficient quantity of phage DNA. With current RNA preparation technology, $\sim 10 \mu \mathrm{g}$ should be sufficient.

2. A high titer library $\left(10^{10} \mathrm{PFU} / \mathrm{mL}\right)$ will yield about $500 \mathrm{ng}$ of phage $\mathrm{DNA} / \mathrm{mL}$, so $20-50 \mathrm{~mL}$ is about the right amount.

3. Add DNase I and RNase A to $50 \mu \mathrm{g} / \mathrm{mL}$. Incubate at $37^{\circ} \mathrm{C}$ for $1 \mathrm{~h}$ with gentle shaking.

4. Transfer to a centrifuge tube, and spin at $12,000 \mathrm{~g}$ for $10 \mathrm{~min}$. Carefully decant the supernatant to a fresh tube.

5. Add $1 / 4 \mathrm{vol}$ of $20 \%$ PEG $8000,2.5 \mathrm{M} \mathrm{NaCl}$, mix well, and incubate on ice for $1 \mathrm{~h}$. Spin at $12,000 \mathrm{~g}$ for $10 \mathrm{~min}$ at $4^{\circ} \mathrm{C}$. Carefully remove the supernatant taking care not to dislodge the phage pellet.

6. Resuspend the phage in a minimum volume of proteinase $\mathrm{K}$ reaction buffer $(10 \mathrm{~m} M$ Tris, $\mathrm{pH} 8.0,5 \mathrm{~m} M$ EDTA, $0.5 \%$ SDS). Take care to resuspend well at this point for maximum yields.

7. Transfer to a $1.5-\mathrm{mL}$ microfuge tube, and add proteinase $\mathrm{K}$ to a final concentration of at least $200 \mu \mathrm{g} / \mathrm{mL}$, and preferably $1 \mathrm{mg} / \mathrm{mL}$. Incubate at $60^{\circ} \mathrm{C}$ for $>30$ min or $37^{\circ} \mathrm{C}$ overnight ( ee Note 15). Be sure that the phage do not clump up during the digestion. Pipet up and down if they do, or you will lose them in the phenol extraction.

8. Phenol:chloroform:isoamyl alcohol-extract and back-extract the organic phase with $20 \%$ of the original volume of TE. Pool the two aqueous phases.

9. Repeat the phenol extraction.

10. Transfer the aqueous phase to a fresh tube, and add 2 vol of EtOH. Now add 0.5 of the original volume of $7.5 \mathrm{M} \mathrm{NH}_{4}$-acetate and mix well (see Note 16). Mix well and store on ice for $30 \mathrm{~min}$. Spin for $20 \mathrm{~min}$ at $4^{\circ} \mathrm{C}$. Rinse the pellet well and dry.

11. Resuspend the pellet in a minimum volume of TE, quantitate, and check a small aliquot for purity by agarose gel electrophoresis.

\subsection{In Vitro Transcription of Phage DNA}

1. Digest $10 \mu \mathrm{g}$ of phage DNA in a final volume of $100 \mu \mathrm{L}$ with $N o t \mathrm{I}$ or XhoI, depending on whether sense or antisense transcripts are desired.

2. Phenol-extract, ethanol precipitate, rinse, and dry the digested DNA. Resuspend at $1 \mathrm{mg} / \mathrm{mL}$.

3. Prepare sense (T3 polymerase and XhoI digest) or antisense (T7 polymerase and NotI digest) RNA using the Ambion Megascript kit following the instructions with the kit. This kit reproducibly gives yields of 70-100 molecules of RNA/molecule of template. We typically use $2 \mu \mathrm{g}$ of template and scale the reaction up $2 \mathrm{X}$.

4. If desired, one can incorporate biotin-21-UTP during the transcription reaction for the production of driver RNA. Add biotin-21-UTP (Clontech) at 1/20 the final concentration of UTP in the transcription reaction. 
5. Recover the RNA after transcription by adding an equal volume of $5 \mathrm{M} \mathrm{LiCl}$ and incubating at $-20^{\circ} \mathrm{C}$ overnight.

6. Spin the precipitate for $20 \mathrm{~min}$ at $4^{\circ} \mathrm{C}$, rinse well, and dry. Resuspend in DEPCtreated $\mathrm{H}_{2} \mathrm{O}$ and quantitate.

7. Add 0.5 volume $7.5 \mathrm{MNH} 4$-acetate and $2.5 \mathrm{vol}$ of ethanol, mix well, and store at $-20^{\circ} \mathrm{C}$. Calculate the new concentration of RNA, and determine the volume/ $\mu \mathrm{g}$ of RNA.

\subsection{Photobiotinylation of RNA $(12,13)$}

1. How much RNA is needed? A maximum of about 60 -fold molar excess of driver RNA is required for a proper subtraction. If necessary, this can be reduced by limiting the short hybridizations to about $4 \mathrm{X}$ molar excess and the long hybridizations to 10fold excess. If one takes the trouble to calculate the amount of cDNA remaining after each subtractive hybridization, the total amount may be significantly reduced.

2. Mix poly (A)+ RNA or in vitro synthesized RNA (10-30 $\mu \mathrm{g} /$ reaction) with $50 \mu \mathrm{g}$ of photoactivatable biotin acetate (Clontech). With the tube tops open and the lamp $6 \mathrm{in}$. from the sample, irradiate on ice for $15 \mathrm{~min}$. Be sure to support the tube in a water bath rack, since the sunlamp rapidly melts the ice.

3. Add 1/10 vol $1 M$ Tris-HCl, $\mathrm{pH} 9.0$, and extract repeatedly with TE-saturated 2butanol to remove unreacted photobiotin (until the butanol phase is clear).

4. $\mathrm{CHCl}_{3}$ extract the RNA, ethanol-precipitate, rinse, and dry. Resuspend in DEPCtreated $\mathrm{H}_{2} \mathrm{O}$ and repeat the photobiotinylation. At this stage, the pellet should be reddish if the biotinylation has been successful.

5. Pool identical RNAs, and store as ethanol precipitates at $-20^{\circ} \mathrm{C}$.

\subsection{Subtractive Hybridization}

1. The subtraction involves two different types of hybridization. We and others $(3,14)$ have found that the typical long hybridizations are inefficient at removing abundant mRNAs, and yield libraries and probes containing significant quantities of housekeeping genes.

2. Prepare first-stranded target cDNA (see Note 17) from poly (A)+ mRNA as described above (preferred) or in vitro sense RNA derived from a target cDNA library. In the latter case one should use $5 \mu \mathrm{g}$ of random hexamers as primers, since one cannot be sure that the poly A tail is present after XhoI digestion. Remove the RNA by adding $10 \mu \mathrm{L}$ of $0.25 M$ EDTA and $30 \mu \mathrm{L} 0.15 N \mathrm{NaOH}$, and incubating for $60 \mathrm{~min}$ at $65^{\circ} \mathrm{C}$. Neutralize with $30 \mu \mathrm{L}$ of $0.15 \mathrm{~N} \mathrm{HCl}$, ethanolprecipitate, rinse, and dry.

3. Sequence of hybridization-perform one short hybridization (steps 4-10) and then one long hybridization (steps 11-17) overnight. Repeat.

4. Short hybridization: spin an appropriate amount of biotinylated driver RNA precipitate (10-fold molar excess to the cDNA) rinse and dry it. Resuspend the RNA in $20 \mu \mathrm{L}$ of hybridization buffer (HBS = $50 \mathrm{~m} M$ HEPES, pH 7.6, 0.2\% SDS, $2 \mathrm{~m} M$ EDTA, $500 \mathrm{~m} M \mathrm{NaCl}$ ).

5. Transfer the resuspended RNA to the tube with the precipitated cDNA, and resuspend it as well. 
6. Transfer the mixture to a $500 \mu \mathrm{L}$ microfuge tube, and overlay with mineral oil. Boil for $3 \mathrm{~min}$, and snap-cool on ice. Incubate for $30 \mathrm{~min}$ at $55^{\circ} \mathrm{C}$.

7. Transfer the aqueous phase to $100 \mu \mathrm{L}$ of hybridization buffer (HB $=$ HBS minus SDS), and add $5 \mu \mathrm{g}$ streptavidin. Mix well, and incubate at room temperature for 5 min.

8. Extract with $100 \mu \mathrm{L}$ of phenol: $\mathrm{CHCl}_{3}$ and centrifuge to separate the phases. Backextract the organic phase with $20 \mu \mathrm{L}$ of $\mathrm{HB}$, and pool the aqueous phases.

9. Repeat the streptavidin and phenol extraction procedure twice.

10. $\mathrm{CHCl}_{3}$-extract the pooled aqueous phases, ethanol-precipitate, rinse, and dry the cDNA.

11. Long hybridization: Spin an appropriate amount of biotinylated driver RNA precipitate (10-fold molar excess to the cDNA), rinse, and dry it. Resuspend the RNA in $20 \mu \mathrm{L}$ of HBS.

12. Transfer the resuspended RNA to the tube with the precipitated cDNA, and resuspend it as well.

13. Carefully draw the mixture into the center of a baked, siliconized, $20-\mu \mathrm{L}$ capillary tube, and seal the ends with a Bunsen burner. Transfer the sealed tube to a beaker of boiling water and heat for $5 \mathrm{~min}$. Transfer the beaker containing the capillary to a $65^{\circ} \mathrm{C}$ water bath, and incubate for $24 \mathrm{~h}$.

14. Remove the beaker from the water bath and slow cool to room temperature. Remove the capillary, and score both ends. Break one, and and transfer the capillary (cut end down) to an Eppendorf tube. While inverted, break the other end, and blow the mixture into the Eppendorf tube. Rinse the capillary with $20 \mu \mathrm{L}$ of $\mathrm{HB}$, and add another $80 \mu \mathrm{L}$ of $\mathrm{HB}$.

15. Add $5 \mu \mathrm{g}$ streptavidin. Mix well and incubate at room temperature for $5 \mathrm{~min}$. Extract with $100 \mu \mathrm{L}$ of phenol: $\mathrm{CHCl}_{3}$, and centrifuge to separate the phases. Back-extract the organic phase with $20 \mu \mathrm{L}$ of $\mathrm{HB}$, and pool the aqueous phases.

16. Repeat the streptavidin and phenol extraction procedure twice.

17. $\mathrm{CHCl}_{3}$-extract the pooled aqueous phases, ethanol-precipitate, rinse, and dry the cDNA.

18. Calculate the yield of subtracted cDNA based on the amount of counts remaining compared with the starting material. One should expect to subtract $>95 \%$ of the starting material.

\subsection{Use of the Subtracted cDNA}

1. Construction of a subtracted cDNA library. Begin with Subheading 3.4.2., step 2-second-strand synthesis.

2. Preparation of a subtracted cDNA probe. Divide the cDNA into three portions. Reagents for random priming are prepared as follows: $1 M$ HEPES, $\mathrm{pH}$ 6.6, DTM (0.1 mM each of dGTP, dTTP in $0.25 M$ Tris-HCl, pH 8.0, $0.025 \mathrm{mM} \mathrm{MgCl}{ }_{2}$, $0.05 \mathrm{~m} M$ BME), OL ( $1 \mathrm{~m} M$ Tris-HCl, $\mathrm{pH} 7.5,1 \mathrm{~m} M$ EDTA containing 90 OD U of random hexanucleotides [Pharmacia]/mL), LS (1 $M$ HEPES:DTM:OL [25:25:7] [v/v]) (15) (see Note 18).

3. The reaction mix contains $11.4 \mu \mathrm{L}$ solution LS, $1 \mu \mathrm{L}$ BSA (Sigma) $(10 \mathrm{mg} / \mathrm{mL}$ ), one-third of the subtracted cDNA fragment and $\mathrm{H}_{2} \mathrm{O}$ to $37.5 \mu \mathrm{L}$. 
4. Boil this reaction for $5 \mathrm{~min}$, and then snap-cool on ice.

5. Add $5 \mu \mathrm{L}$ each of $\alpha-\left[{ }^{32}\right.$-P]dATP and $\mathrm{dCTP}(3000 \mathrm{Ci} / \mathrm{m} M)$ and $2.5 \mathrm{U}$ of the Klenow fragment of DNA polymerase I (Pharmacia).

6. Incubate for $2 \mathrm{~h}$ to overnight at room temperature.

7. Remove the unincorporated nucleotides by Sephadex G-50 spun-column chromatography as above.

\subsection{Library Screening}

1. Plate the library to be screened at relatively low density ( 5-10,000 phage/150$\mathrm{mm}$ plate) to minimize the number of purification steps required. Concerning the amplification step described above, it is best to plate the phage in the morning, observe their growth during the day, and remove the plates to $4^{\circ} \mathrm{C}$ when plaques are relatively large ( 2-mm), but still well isolated from each other.

2. Lift dupicate filters from each plate, the first for $3 \mathrm{~min}$ and the second for $6 \mathrm{~min}$ (see Note 19). Store the filters plaque side up on Whatman 3MM paper until all lifts are completed. Be sure to position registration marks carefully for accuracy in aligning the autoradiograms later.

3. Denature the phage by placing the filters (plaque side up) on pads of Whatman 3MM paper saturated with the following solutions for 3' each (10): Solution $1-0.5 \mathrm{~N}$ $\mathrm{NaOH}, 1.5 \mathrm{M} \mathrm{NaCl}$; Solution-2 1.0 M Tris-HCl, pH 7.5, $1.5 \mathrm{M} \mathrm{NaCl}$; Solution $3-2 \mathrm{X}$ SSC. Next, transfer the filters to $3 \mathrm{MM}$ paper, and allow to air-dry.

4. Interleave the filters between circles of filter paper, and secure the entire stack with tape. Bake at $80^{\circ} \mathrm{C}$ for $30 \mathrm{~min}$.

5. After baking, transfer the filters to a dish of $50 \mathrm{mM} \mathrm{NaOH}$, and incubate for 15 min with shaking. This step reduces later background. Rinse with at least four changes of distilled $\mathrm{H}_{2} \mathrm{O}$ for a total of $15 \mathrm{~min}$.

6. Transfer the filters to a hybridization bag, and add $2 \mathrm{~mL} /$ filter of Church's buffer (7\% SDS, $0.5 \mathrm{M} \mathrm{NaPO}_{4}, \mathrm{pH}$ 7.2) (16). Prehybridize at $65^{\circ} \mathrm{C}$ for a convenient time, usually $15 \mathrm{~min}$ to several hours. Up to 20 filters $(132 \mathrm{~mm})$ can be processed/bag.

7. Remove the prehybridization solution and add fresh Church's buffer containing $5 \%$ w/v Dextran sulfate (Pharmacia) at $750 \mu \mathrm{L} /$ filter. Denature the probe by adding 0.1 vol $2 \mathrm{~N} \mathrm{NaOH}$ and incubating at room temperature for $5 \mathrm{~min}$. Add the denatured probe directly to the bag, seal, and mix well. Hybridize at $65^{\circ} \mathrm{C}$ overnight with shaking if possible.

8. Remove and save the hybridization solution at $-20^{\circ} \mathrm{C}$ (add fresh probe to it for subsequent screening). Wash the filters $3 \times 20^{\prime}$ at $65^{\circ} \mathrm{C}$ in $0.5 \mathrm{X} \mathrm{SSC}, 0.1 \%$ SDS. Expose to X-ray film with two intensifying screens overnight or longer.

9. Align the duplicate autoradiographs, and pick plaques with the wide end of a Pasteur pipet, which appear on both filters to $1 \mathrm{~mL}$ of SM buffer.

10. Plate several dilutions of each plaque stock, and incubate overnight at $37^{\circ} \mathrm{C}$. Select a plate with $\sim 50$ plaques for the next round of screening. After this round, the individual plaques should be pure and can be picked with the narrow end of a Pasteur pipet. 
11. Convert the phage to plasmids according to the Stratagene protocol provided with the ZAPII vector or library.

\section{Notes}

1. Be sure to use the appropriate laboratory technique when handling radioactive and toxic materials. Consult a laboratory safety manual if you are in doubt regarding what proper practices are. Methyl mercuric hydroxide is quite toxic and should be handled with extreme care in a fume hood. This toxicity is balanced by its extremely potent and reversible denaturing activity. Each new batch of methyl mercuric hydroxide should be tested for performance in denaturing gel electrophoresis as described in ref.9. If sharp bands are not observed, purify the methyl mercuric hydroxide by stirring for $2 \mathrm{~h}$ at room temperature with a mixed-bed resin, such as Amberlite MB-1 or equivalent. Remove the resin and other debris by passing through a $0.2-\mu \mathrm{m}$ syringe filter. Store in small aliquots at $-70^{\circ} \mathrm{C}$. Be sure to dispose of mercury waste appropriately.

2. This step is required to repair the cDNA and render it blunt-ended prior to linker ligation.

3. This additional blunting is required to repair any damage caused by EcoRI methylase. We have noticed variable amounts of nuclease activity in methylases and think this extra step is prudent.

4. We usually buy phosphorylated linkers as well as unphosphorylated ones, since it is more efficient to synthesize the linker with the phosphate on than to add it later enzymatically.

5. One should be careful that the linkers are in sufficient excess in this reaction. This, of course, depends on the yield of cDNA. Assume an average cDNA length of $1 \mathrm{~kb}$ in the first strand reaction and calculate the number of picomoles of ends. Be sure that the linkers are in 50- to 100-fold molar excess to ensure that cDNAs are not artifactually ligated to each other.

6. The addition of T4 RNA ligase stimulates blunt-end ligation up to 10-fold. Furthermore, RNA ligase is capable of ligating linker molecules to RNA remaining at the 5'-end of cDNA. It is quite probable that some of the longest cDNA molecules will have a few nucleotides of RNA left at the 5'-end, which RNase H can not remove. If RNA ligase is not added, then linkers can not be added to this end and these cDNAs will be lost from the library.

7. Check for ligation and digestion by running an $8 \%$ polyacrylamide gel in TBE before and after digestion samples. A typical protein gel apparatus is appropriate. Run the gel at 300-400 V, and stop it when the bromophenol blue goes half way down. Expose to film for several hours, or dry the gel down and expose for an appropriate time. Expect to see a ladder of linkers in the undigested sample, it should be gone in the EcoRI-digested sample, and there should be two bands near the bottom of the gel. If the XhoI digest was done separately, expect to see one additional band larger than the two in the EcoRI digest. If the ligation or either digestion did not work, then go back to the blunt-ending step, and repeat carefully checking each step individually. 
8. Alternatively, the EcoRI and XhoI digests can be performed together using buffer $\mathrm{H}$, but this does not permit checking that each step has worked. We usually do the digestions separately when testing new batches of enzymes and reagents, but otherwise do them together to save time.

9. Use a sterile, plugged, individually wrapped plastic pipet suitable for tissue culture. Score the pipet in the middle of the cotton. Break off and remove the cotton. Make a tiny ball of polyester wool, push into the column top with forceps, and blast into the bottom with compressed air or gas (available at most lab benches). Polyester wool used for aquarium filtration and is available at most pet shops.

10. Proper technique is critical here for good separation. Allow the liquid in the column to drain to the top of the bed. Apply $50 \mu \mathrm{L}$ of cDNA carefully, and allow to run in. While this is going on, reattach the reservoir, and carefully add column buffer when the cDNA has fully entered the column. Of course, the column should not be allowed to run dry at any point or else resolution will be compromised.

11. Using Sepharose Cl-4B and the column system described above, the first fraction following the cDNA peak is about $500 \mathrm{bp}$. Pool the fractions from here to the beginning.

12. Take care not to overdry the DNA, or it will be quite difficult to resuspend. One to $2 \mathrm{~min}$ in the Speed-Vac are sufficient.

13. Stratagene recommends a 2-h incubation at room temperature. We have used up to $6 \mathrm{~h}$ with equally good results.

14. Although it is slightly more trouble to maintain cells on minimal plates and grow them in minimal media, the increased plating efficiency and reproducibility are worth it. Some strains, most notably C600 HflA ${ }^{150}$ and Y1090, throw off resistant mutants at a high rate. Growth on media with maltose as the carbon source minimizes this phenomenon.

15. Proteinase $\mathrm{K}$ works well at elevated temperatures, but is denatured at temperatures above $65^{\circ} \mathrm{C}$. This is a good step to let go overnight if desired.

16. When precipitating large amounts of DNA, you will get cleaner precipitates by adding the alcohol first, mixing well, and then adding the salt and mixing well again. Mix well, and store on ice, $-20^{\circ} \mathrm{C}$, or $-70^{\circ} \mathrm{C}$ for $10+\min$. For reasonable amounts of DNA, these three are about equivalent. The centrifugation time is much more critical. We typically use ice for $30 \mathrm{~min}$ followed by a $20 \mathrm{~min}$ spin at room temperature. For small quantities of DNA, overnight at $-20^{\circ} \mathrm{C}$ gives superior recoveries.

17. If the production of a subtracted cDNA library is desired, then one is practically limited to using poly (A)+ RNA from the target tissue as the source of material. If a subtracted probe is being prepared, then either poly (A)+ RNA or RNA synthesized in vitro from an existing library is adequate. Whenever there is sufficient poly (A)+ RNA available, its use is preferred to minimize changes in complexity of the target RNA.

18. There are a number of high-quality kits available for labeling DNA by random priming. If you choose a commercial kit, be sure that it can be adapted to use two radionucleotides, since the probe must be of very high-specific activity to detect rare clones.

19. The choice of nitrocellulose or nylon membranes depends on the number of times the library will be screened. For one to three screenings we prefer to use sup- 
ported nitrocellulose (e.g., BAS/NC, Schleicher and Schuell, Keene, NH) owing to its inherent high signal-to-noise ratio. If the library may be screened three or more times, them it makes sense to use a nylon membrane such as Nytram (Schleicher and Schuell). We have has intermittent difficulties with nylon membranes from other manufacturers and recommend each batch prior to using it.

\section{Acknowledgments}

This work was supported by the American Cancer Society (Grant DB-36 to B. B.) and the G. Harold and Leila Y. Mathers Charitable Foundation (J. C. I. B.).

\section{References}

1. St. John, T. P. and Davis, R. W. (1979) Isolation of galactose-inducible DNA sequences from Saccharomyces cerevisiae by differential plaque filter hybridization. Cell 16, 443-452.

2. Sargent, T. D. and Dawid, I. B. (1983) Differential gene expression in the gastrula of Xenopus laevis. Science 222, 135-139.

3. Wang, Z. and Brown, D. D. (1991) A gene expression screen. Proc. Natl. Acad. Sci. USA 88, 11,505-11,509.

4. Aasheim, H. C., Deggerdal, A., Smeland, E. B., and Hornes, E. (1994) A simple subtraction method for the isolation of cell-specific genes using magnetic monodisperse polymer particles. Biotechniques 16, 716-721.

5. Hara, E., Kato, T., Nakada, S., Sekiya, S., and Oda, K. (1991) Subtractive cDNA cloning using oligo(dT)30-latex and PCR: isolation of cDNA clones specific to undifferentiated human embryonal carcinoma cells. Nucleic Acids Res. 19, 7097-7104.

6. Li, W. B., Gruber, C. E., Lin, J. J., Lim, R., D'Alessio, J. M., and Jessee, J. A. (1994) The isolation of differentially expressed genes in fibroblast growth factor stimulated $\mathrm{BC} 3 \mathrm{H} 1$ cells by subtractive hybridization. Biotechniques 16, 722-729.

7. Lopez-Fernandez, L. A. and del Mazo, J. (1993) Construction of subtractive cDNA libraries from limited amounts of mRNA and multiple cycles of subtraction. Biotechniques 15, 654-659.

8. Sharma, P., Lonneborg, A., and Stougaard, P. (1993) PCR-based construction of subtractive cDNA library using magnetic beads. Biotechniques 15, 610-612.

9. Maniatis, T., Fritsch, E. F., and Sambrook, J. (1989) Molecular Cloning: A Laboratory Manual, 2nd ed. Cold Spring Harbor Laboratory Press, Cold Spring Harbor, NY.

10. Han, J. H., Stratowa, C., and Rutter, W. J. (1987) Isolation of full-length putative rat lysophospholipase cDNA using improved methods for mRNA isolation and cDNA cloning. Biochemistry 26, 1617-1625.

11. Blumberg, B., Wright, C. V. E., De Robertis, E. M., and Cho, K. W. Y. (1991) Organizer-specific homeobox genes in Xenopus laevis embryos. Science 253, 194-196.

12. Forster, A. C., McInnes, J. L., Skingle, D. C., and Symons, R. H. (1985) Non-radioactive hybridization probes prepared by the chemical labelling of DNA and RNA with a novel reagent, photobiotin. Nucleic Acids Res. 13, 745-761. 
13. Sive, H. L. and St. John, T. (1988) A simple subtraction hybridization technique employing photoactivatable biotin and phenol extraction. Nucleic Acids Res. 16, $10,937$.

14. Sasaki, Y. F., Ayusawa, D., and Oishi, M. (1994) Construction of a normalized cDNA library by introduction of a semi-solid mRNA-cDNA hybridization system. Nucleic Acids Res. 22, 987-992.

15. Feinberg, A. P. and Vogelstein, B. (1983) A technique for radiolabelling DNA restriction endonuclease fragments to high specific activity. Anal. Biochem. 132, 6-13.

16. Church, G. M. and Gilbert, W. (1984) Genomic sequencing. Proc. Natl. Acad. Sci. USA 81, 1991-1995. 